\title{
Neuromedin $U$ enhances proliferation of ACTH-stimulated adrenocortical cells in the rat
}

\author{
MARCIN TREJTER $^{1}$, DIEGO GUIDOLIN ${ }^{2}$, MAGDALENA NOWAK $^{1}$, VERONICA MACCHI ${ }^{2}$, \\ MARIOLA MAJCHRZAK ${ }^{1}$, RAFFAELE DE CARO ${ }^{2}$ and LUDWIK K. MALENDOWICZ ${ }^{1}$
}

\author{
${ }^{1}$ Department of Histology and Embryology, Poznan University of Medical Sciences, Poznan PL-60781, Poland; \\ ${ }^{2}$ Department of Human Anatomy and Physiology, Section of Anatomy, University of Padua, Padua I-35121, Italy
}

Received September 5, 2008; Accepted November 6, 2008

DOI: 10.3892/ijmm_00000106

\begin{abstract}
Neuromedin U (NMU) is a brain-gut peptide involved in the regulation of the hypothalamic-pituitaryadrenal axis and adrenocortical cell proliferation. In this study, we investigated the effects of NMU8 (three subcutaneous injections of $6.0 \mathrm{nmol} / 100 \mathrm{~g}, 24,16$ and $8 \mathrm{~h}$ before autopsy) on the adrenal glands of rats treated for 2 or 4 days with a low $(2 \mu \mathrm{g} / 100 \mathrm{~g}$ body weight/24 h) or a high $(8 \mu \mathrm{g})$ dose of adrenocorticotropic hormone (ACTH). As revealed by RT-PCR, ACTH treatment did not prevent expression of NMUR1 in rat adrenal cortex. At day 4 of ACTH administration, the weight of adrenals was lower than at day 2. NMU8 administration prevented ACTH-induced increases of adrenal weight at day 2 of the experiment. ACTH plasma concentrations were increased in all $\mathrm{ACTH}$-administered rats. NMU8 administration increased ACTH plasma concentration at day 2 of the lower ACTH dose-treated group while it reduced the ACTH plasma level at day 4 in the higher ACTH dose-administered rats. In all groups of ACTH-treated rats, NMU8 changed neither aldosterone nor corticosterone plasma concentrations. In the zona glomerulosa (ZG), NMU8 increased metaphase index at days 2 and 4 in the lower ACTH dose-treated group and had no statistically significant effect in rats treated with the higher ACTH dose. In the zona fasciculata (ZF), NMU8 administration increased metaphase index at day 2 in the lower ACTH dose-treated group but reduced metaphase index at day 4 in the higher dose ACTHadministered rats. NMU8 reduced the number of cells per unit area both in $\mathrm{ZG}$ and $\mathrm{ZF}$ at day 2 in the higher ACTH dose-treated rats. In the remaining groups NMU8 did not produce statistically significant changes in the number of cells per unit area. Thus, our findings demonstrate that exo-
\end{abstract}

Correspondence to: Professor L.K. Malendowicz, Department of Histology and Embryology, Poznan University of Medical Sciences, 6 Swiecicki St., Poznan PL-60781, Poland

E-mail: 1km@amp.edu.pl

Key words: neuromedin U, adrenocorticotropic hormone, corticosterone, aldosterone, adrenal growth, proliferative activity genous NMU may stimulate proliferation primarily of the cortical ZG cells in rats administered with ACTH, although at high doses of exogenous corticotropin an opposite effect occurred.

\section{Introduction}

Neuromedin U (NMU), neuromedin S (NMS) and NMU receptors (the peripheral NMUR1 and the central NMUR2) are involved in the regulation of a variety of physiological systems (reviewed in ref. 1) and play a pivotal role in the regulation of the hypothalamic-pituitary-adrenal axis (HPA) (1-15). Recent data indicate that NMU is also involved in regulation of adrenocortical growth.

The main mechanisms responsible for adrenocortical growth in vivo are hyperplasia and hypertrophy, however a variety of endocrine and neural inputs may be involved in adrenal enlargement. Dallman (16) distinguishes four types of adrenal cortex growth and each of them is differentially regulated. Enucleation-induced adrenocortical regeneration resembles growth of the gland at early embryogenesis and depends on several neural and endocrine signals (17-21), while unilateral adrenalectomy-induced compensatory growth is primarily neurally mediated (16,22-25). Adrenocortical growth related to maturation is probably regulated by numerous growth factors while adrenocorticotropic hormone (ACTH)-induced growth primarily depends on adrenocortical cell proliferation $(16,26)$. Recently, we demonstrated the stimulating effects of exogenous NMU on enucleationinduced adrenocortical regeneration (27), and on proliferation of cultured rat adrenocortical cells (28). On the contrary, this neuropeptide was found not to interfere with adrenocortical growth related to maturation (28) and was observed to inhibit unilateral adrenalectomy-induced compensatory adrenal growth (29). Therefore, the present study was undertaken to investigate the effects of NMU on ACTH-induced adrenal growth in rats.

\section{Materials and methods}

Animals and reagents. Female Wistar rats (final body weight 120-130 g) were kept under a $14: 10$ h light-dark cycle (illumination onset at 6:00 a.m.) at $23^{\circ} \mathrm{C}$, and maintained on a standard diet and tap water ad libitum. The study protocol was 
approved by the Local Ethics Committee for Animal Studies. NMU8 was purchased from Bachem Feinchemikalien AG (Bubbendorf, Switzerland), ACTH (Synacthen depot) from Ciba (Basle, Switzerland), and vincristine from GedeonRichter (Budapest, Hungary). All other chemicals and reagents were provided by Sigma-Aldrich or POCh (Gliwice, Poland).

Experimental design. Groups of rats $(\mathrm{n}=8)$ were administered with subcutaneous ACTH injections of 2 or $8 \mu \mathrm{g} / 100 \mathrm{~g}$ body weight $/ 24 \mathrm{~h}$, for 2 or 4 days. Four appropriate groups were administered 3 subcutaneous injections $(24,16$ and $8 \mathrm{~h}$ before sacrifice) of $6.0 \mathrm{nmol} / 100 \mathrm{~g}$ body weight of NMU8, dissolved in $0.2 \mathrm{ml} 0.9 \%$ saline. The other four groups (control rats) received subcutaneous injection of the vehicle. Three hours before sacrifice all rats were administered with an intra-peritoneal (i.p.) injection of $0.1 \mathrm{mg} / 100 \mathrm{~g}$ body weight of vincristine. The animals were decapitated at 11:00 a.m., and their trunk blood was collected in the presence of EDTA $(1 \mathrm{mg} / \mathrm{ml})$. Plasma was separated and stored at $-36^{\circ} \mathrm{C}$ for hormone assay. Adrenals were removed, weighed, fixed in Bouin's solution and embedded in paraffin for metaphaseindex assay and morphometric estimations.

Metaphase index and morphometry. Sections (6 $\mu \mathrm{m})$ were stained with hematoxylin and eosin and metaphase index (number of vincristine-arrested metaphase cells per 1,000 cells) was calculated at a magnification of $x 400$, by counting 5,000 cells in the zona glomerulosa (ZG) or zona fasciculata (ZF) of the adrenal gland (30-32). The number of nuclei of adrenocortical cells was counted at a magnification of $x 400$ in 50 fields (area of one field: $0.003 \mathrm{~mm}^{2}$ ) of each adrenal, and the number of nuclei per $\mathrm{mm}^{2}$ was calculated.

NMURl gene expression (RT-PCR). NMUR1 gene expression in the adrenal cortex was examined as detailed previously (27-29). The following primers were used: sense (481-500), 5'-GCCATCTGGGTCTTCGCTAT-3' and antisense (797816), 5'-CACCTGTCTGCGTTCCCTAT-3' (336 bp; accession number, AF242873). The primers were purchased from the Laboratory of DNA Sequencing and Oligonucleotide Synthesis, Institute of Biochemistry and Biophysics, Polish Academy of Sciences, Warsaw.

Hormone assay. Plasma ACTH concentrations were measured by RIA, using a commercial kit purchased from Diagnostic Product Co., Los Angeles, CA, USA, as previously detailed $(27,28,33,34)$. ACTH RIA: sensitivity $8 \mathrm{pg} / \mathrm{ml}$, intra- and inter-assay CVs 7 and 9\%, respectively. Cross-reactivity: ACTH (1-24), $100 \%$; $\alpha$-MSH, $0.3 \%$; the remaining pituitary hormones, $<0.001 \%$.

Aldosterone and corticosterone were extracted from plasma and their concentrations were measured by RIA, using $\left[1,2,6,7-{ }^{3} \mathrm{H}\right]$-aldosterone and $\left[1,2,6,7-{ }^{3} \mathrm{H}\right]$-corticosterone (Amersham, UK; S.A.; $1.96 \mathrm{Tbq} / \mathrm{mmol}$ ) and antisera developed in rabbit (Sigma, St. Louis, MO, USA) $(19,27,28,33,34)$. Aldosterone RIA sensitivity was $5 \mathrm{pg} / \mathrm{ml}$ and the cross reactivity was: aldosterone, $100 \%$; 17 -iso-aldosterone and other steroids, $<0.1 \%$. Intra- and inter-assay variations amounted to 5 and $7 \%$, respectively. Corticosterone RIA sensitivity was

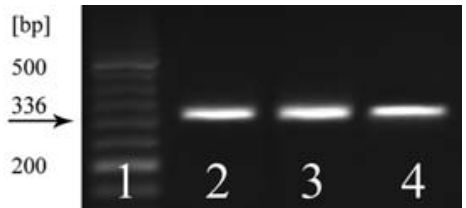

Figure 1. Expression of the neuromedin U receptor 1 (NMUR1) gene in the adrenal cortex of ACTH-treated rats. PCR products were separated by electrophoresis in $1.2 \%$ agarose gel and stained with ethidium bromide Amplification by means of RT-PCR with specific primer RNA revealed the presence of reaction products with the expected size of $336 \mathrm{bp}$. Lanes: 1 , marker; 2. adrenal cortex of intact rat; 3 , adrenal cortex of rat treated for 2 days with ACTH $(8 \mu \mathrm{g} / 100 \mathrm{~g} /$ day $)$; 4 , adrenal cortex of rat treated for 4 days with ACTH $(8 \mu \mathrm{g} / 100 \mathrm{~g} /$ day $)$

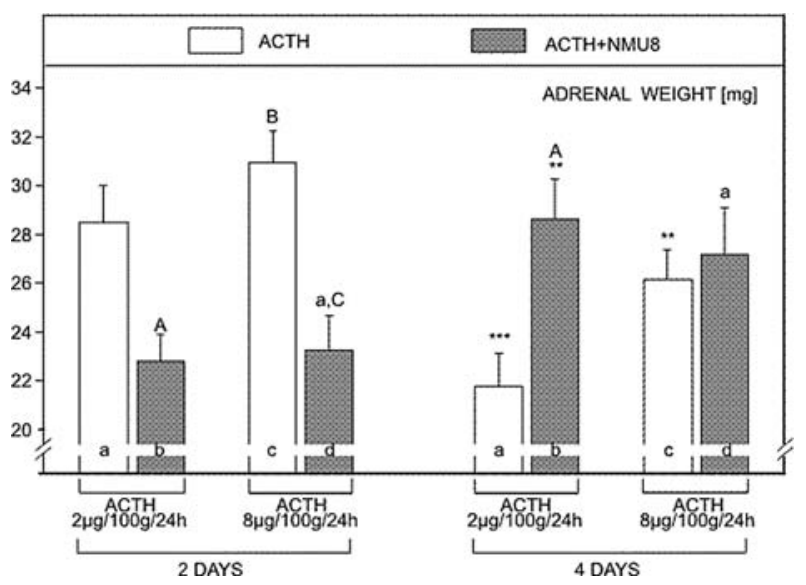

Figure 2. Effects of neuromedin U8 (NMU8) (6 nmol/100 g body weight/per injection) applied 24, 16 and $8 \mathrm{~h}$ prior to autopsy, on adrenal weight of mature female rats treated with ACTH ( 2 or $8 \mu \mathrm{g} / 100 \mathrm{~g} /$ day) for 2 or 4 days Three hours before autopsy the rats were i.p. injected with vincristine at the dose of $0.1 \mathrm{mg} / 100 \mathrm{~g}$. Bars represent means and \pm SE. Each group $n=8$ Letters in bars $(a, b, c, d)$ indicate appropriate group for statistical comparisons. Statistical comparison of differences by Duncan's multiple range test: as compared to the indicated group at the same day the differences are significant at: lower cases $\mathrm{p}<0.05$; capitals $\mathrm{p}<0.01$. Comparison with the analogous group at day 2 of the experiment using Student's t test: the differences are significant at: ${ }^{*} \mathrm{p}<0.05 ;{ }^{*} \mathrm{p}<0.02$; ${ }^{* * *} \mathrm{p}<0.01 ;{ }^{* * * *} \mathrm{p}<0.001$.

$50 \mathrm{pg} / \mathrm{ml}$ and cross-reactivity was: corticosterone and cortisol, $100 \%$; 11-deoxy-corticosterone and progesterone, $2 \%$, other steroids, $<0.001 \%$. Intra- and inter-assay variations amounted to 7 and $9 \%$, respectively.

Statistics. Data are expressed as means \pm SEM and the statistical significance of the differences among the experimental groups was estimated using ANOVA, followed by Duncan's multiple range tests and the unpaired Student's t-test.

\section{Results}

RT-PCR study revealed the presence of NMUR1 mRNA in adrenal cortex of rats treated with ACTH for 2 or 4 days, as well as in the glands of intact animals (Fig. 1). Amplification by means of RT-PCR using specific primer RNA revealed the presence of reaction products with an expected size of $336 \mathrm{bp}$. 

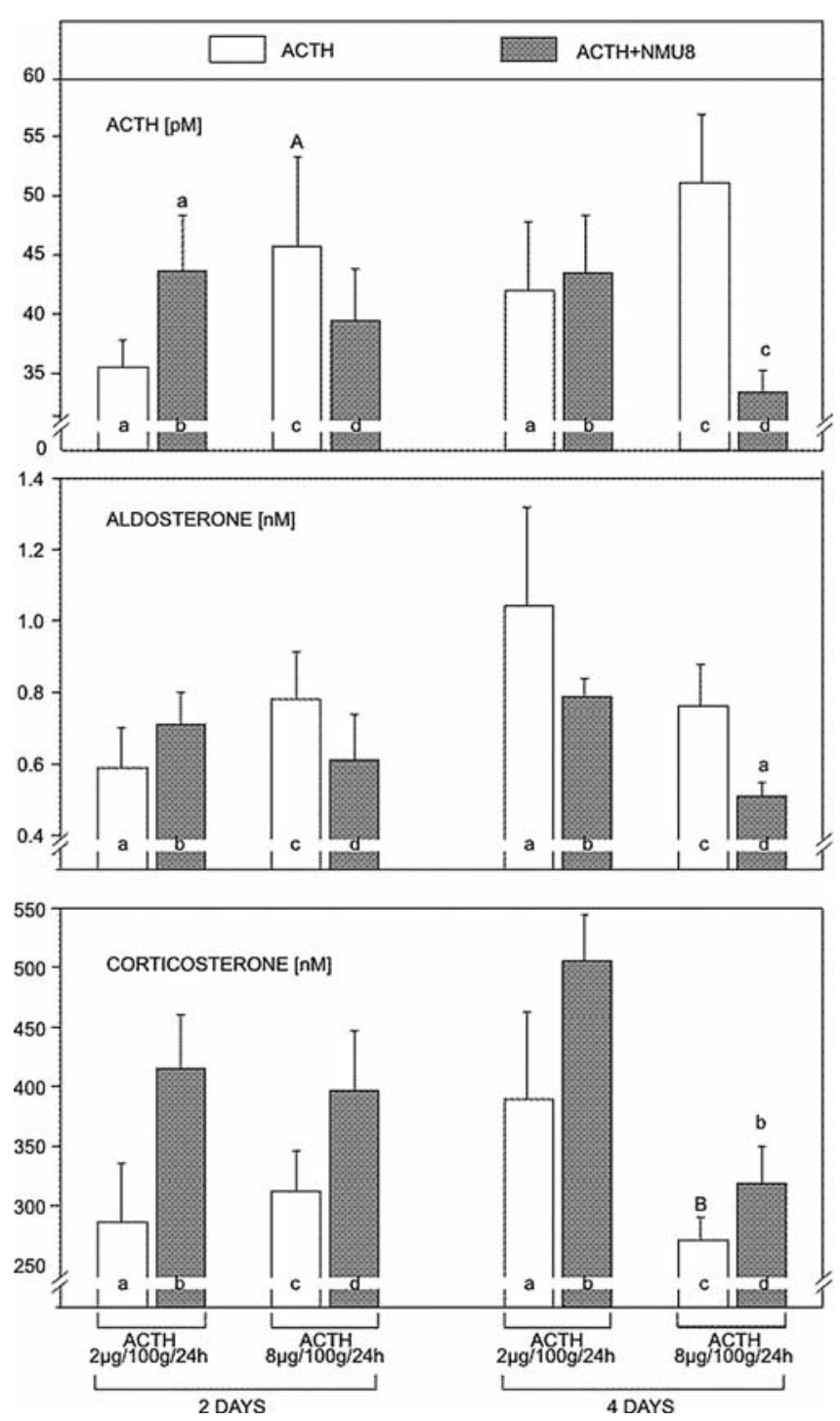

Figure 3. Effects of neuromedin U8 (NMU8) $(6 \mathrm{nmol} / 100 \mathrm{~g}$ body weight/per injection) applied 24,16 and $8 \mathrm{~h}$ prior to autopsy, on plasma ACTH (pM); aldosterone $(\mathrm{nM})$ and corticosterone $(\mathrm{nM})$ levels, in mature female rats treated with ACTH ( 2 or $8 \mu \mathrm{g} / 100 \mathrm{~g} /$ day) for 2 or 4 days. Three hours before autopsy the rats were i.p. injected with vincristine at the dose of $0.1 \mathrm{mg} / 100 \mathrm{~g}$. Detailed explanations are provided in Fig. 2. The basal plasma ACTH concentration in the rat was $15-20 \mathrm{pM}$.

As shown in Fig. 2, the adrenal weight at day 4 of the experiment for both lower and higher dose ACTH-treated rats was lower than at day 2. NMU8 administration prevented ACTH-induced increases of adrenal weight at day 2 in both the lower and the higher ACTH dose-treated rats. On the contrary, NMU8 further increased adrenal weight at day 4 in the lower ACTH dose-treated animals and did not affect adrenal weight at day 4 in rats administered with the higher dose of ACTH.

ACTH plasma concentrations were increased in all ACTH-administered rats; basal ACTH plasma levels being 15-20 pM in rats receiving no ACTH treatment. NMU8 administration increased ACTH plasma concentration at day 2 in the lower ACTH dose-treated group but reduced ACTH plasma level at day 4 in the higher ACTH dose-administered rats. In all groups of ACTH-treated rats NMU8 did not
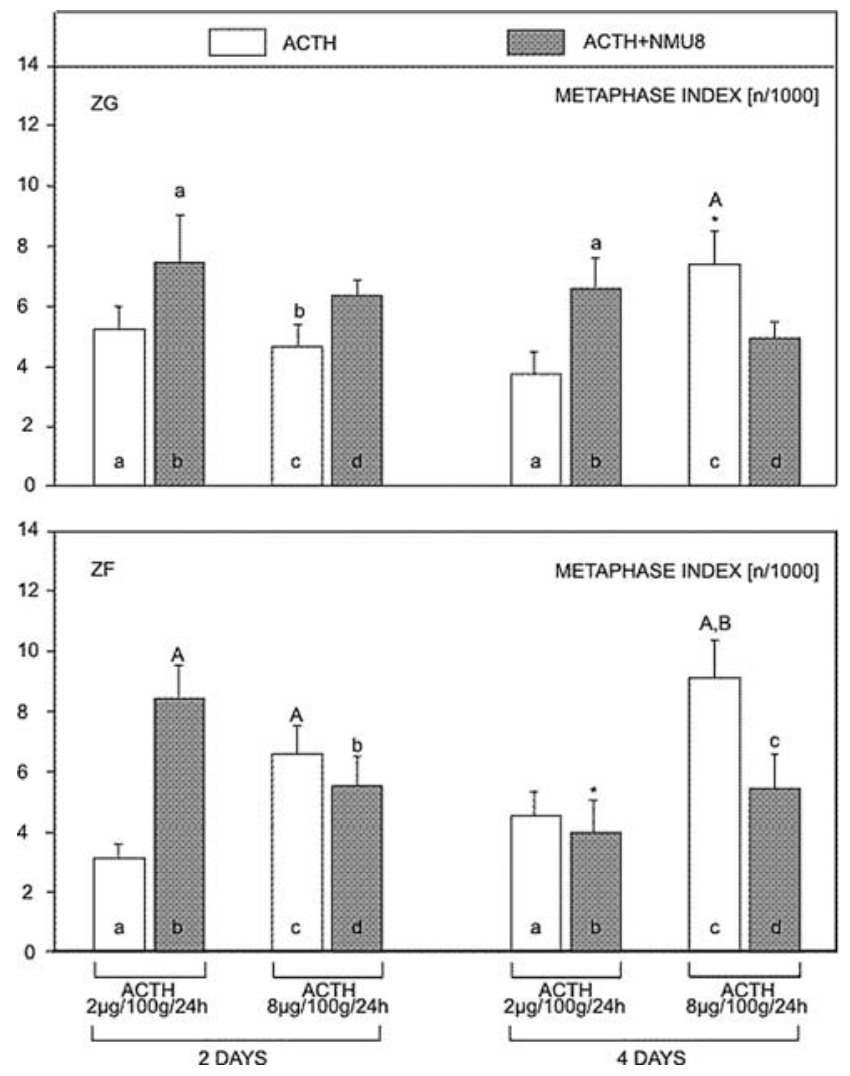

Figure 4. Effects of neuromedin U8 (NMU8) $(6 \mathrm{nmol} / 100 \mathrm{~g}$ body weight/per injection) applied 24, 16 and $8 \mathrm{~h}$ prior to autopsy, on adrenal metaphase index $(\mathrm{n} / 1000)$ in zona glomerulosa $(\mathrm{ZG})$ and zona fasciculata $(\mathrm{ZF})$ of mature female rats treated with ACTH ( 2 or $8 \mu \mathrm{g} / 100 \mathrm{~g} /$ day) for 2 or 4 days. Three hours before autopsy the rats were i.p. injected with vincristine at the dose of $0.1 \mathrm{mg} / 100 \mathrm{~g}$. Detailed explanations are provided in Fig. 2.

change aldosterone and corticosterone plasma concentrations (Fig. 3).

In the ZG, NMU8 increased metaphase index at days 2 and 4 in the lower ACTH dose-treated group, and had no statistically significant effect in rats treated with the higher ACTH dose. In the ZF, NMU8 administration increased metaphase index at day 2 in the lower ACTH dose-treated group but reduced metaphase index at day 4 in the higher ACTH dose-administered rats (Fig. 4). NMU8 reduced the number of cells per unit area both in ZG and ZF at day 2 in the higher ACTH dose-treated rats. In the remaining groups, NMU8 did not produce statistically significant changes in the number of cells per unit area (Fig. 5).

\section{Discussion}

Within the HPA axis, individual components of NMU, NMS and NMU receptors system show rather tissue-specific expression. In the hypothalamus, NMS and NMUR2 genes are highly expressed; in adenohypophysis, NMU, NMUR1 and NMUR2 (at a relatively low level) are present while in the adrenal cortex and medulla only NMUR1 gene expression is found (10,35-48). Within the HPA axis, NMU stimulates CRH synthesis and secretion, enhances pituitary ACTH and adrenal corticosterone and aldosterone secretion. Furthermore, 

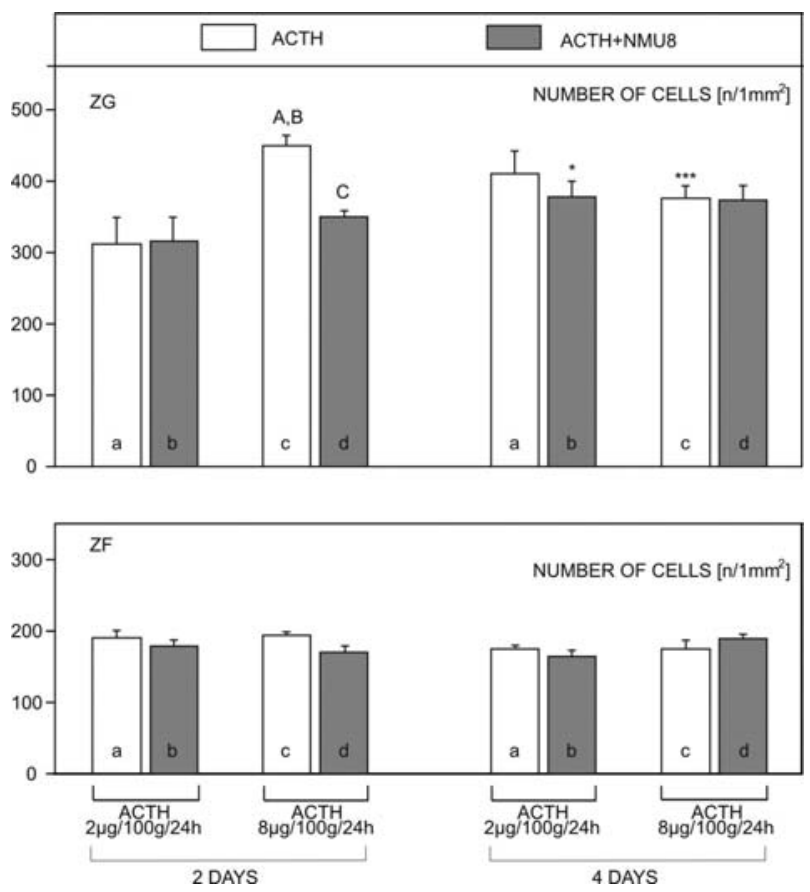

Figure 5. Effects of neuromedin U8 (NMU8) ( $6 \mathrm{nmol} / 100 \mathrm{~g}$ body weight/per injection) applied 24, 16 and $8 \mathrm{~h}$ prior to autopsy, on number of nuclei of adrenocortical cells per unit area $\left(\mathrm{n} / 1 \mathrm{~mm}^{2}\right)$ in zona glomerulosa $(\mathrm{ZG})$ and zona fasciculata (ZF) of mature female rats treated with ACTH $(2$ or $8 \mu \mathrm{g} / 100 \mathrm{~g} /$ day $)$ for 2 or 4 days. Three hours before autopsy the rats were i.p. injected with vincristine at the dose of $0.1 \mathrm{mg} / 100 \mathrm{~g}$. Detailed explanations are provided in Fig. 2.

NMU directly affects adrenocortical cell steroidogenesis, an effect probably dependent on the presence of the CRH-ACTH system of the adrenal medulla (1-15,28).

This study aimed to investigate whether NMU affects ACTH-induced adrenocortical growth rats. Earlier we found NMUR1 mRNA in the rat adrenal cortex, while NMU, NMS and NMUR2 mRNAs were not found (48). In this study we found that adrenal cortex of ACTH-treated rats was also provided with NMUR1 mRNA.

It is well documented that in vivo ACTH administration or its hypersecretion causes primarily adrenocortical cellular hypertrophy, which is subsequently followed by hyperplasia $(16,31,49-57)$. On the contrary, the direct in vitro effect of ACTH involves inhibition of adrenocortical cell proliferation and stimulation of the cell specialized functions, that is corticosterone secretion $(28,34,58-60)$.

Our observations revealed that after 2 days of ACTH administration the adrenal gland weight was heavier than after 4 days of treatment with ACTH. As is known, the adrenal cortex is an endocrine tissue with a rich vascular supply and ACTH results in a potent stimulation of adrenal blood flow (61-64). ACTH-induced increased adrenal blood flow is transient and, therefore, the changes in the weight of adrenals may be connected with altered response of the cortical vasculature to chronically elevated blood corticotropin levels. In ACTH-treated rats, NMU8 either reduced (at day 2 in both the lower and the higher ACTH dose-treatment groups) or increased (at day 4 in the lower ACTH dose-administered rats) the adrenal weight. The above discussed NMU-evoked changes in the adrenal weights may be connected with the polypeptide effects on adrenal vasculature or its stimulatory action on a sympathetic nervous system (65-67).

Effects of NMU8 on ACTH plasma concentrations varied depending on ACTH doses and days of treatment. NMU8 increased plasma corticotropin concentrations at day 2 in the lower ACTH dose-treated rats while it reduced the ACTH level at day 4 in the higher ACTH dose-administered animals. Moreover, plasma aldosterone and corticosterone levels of ACTH-treated rats were not significantly altered by NMU8 injections. Despite the lack of major alterations in hormone levels, NMU8 exerted a stimulating effect on proliferative activity of rat adrenocortical cells. Such a proliferative response was observed in the ZG at days 2 and 4 in the lower ACTH dose-treated animals and in the ZF at day 2 in the lower ACTH dose-administered rats. The opposite effect was found in the $\mathrm{ZF}$ at day 4 in the higher ACTH dose-treated rats. Thus, the stimulating effects of NMU8 on ZG cell proliferation in ACTH-treated rats was evident at days 2 and 4 of the experiment and in animals administered with the lower ACTH dose $(2 \mu \mathrm{g} / 100 \mathrm{~g}$ body weight/24 h) while such a response was not observed in rats administered with the higher ACTH doses. Changes in the rate of ZG cell proliferative activity in ACTH-NMU8-treated rats were not paralleled by changes in plasma ACTH concentrations. These findings suggest that the stimulating effect of NMU8 on ZG cell proliferation in the rat is independent of ACTH action on the adrenal cortex. However, large corticotropin doses have appeared to prevent the stimulating effects of NMU8 on mitotic activity in the cortical ZG. It remains to be established whether these differences depend on altered sensitivity of cells in rats administered with different doses of ACTH. Also we cannot exclude the possibility that these changes may be dependent on activation of local compensatory mechanisms in rats treated with high ACTH doses. The stimulating effect of NMU8 on ZG cells in ACTH-treated rats was similar to that evoked by ACTH alone. ZG of adrenal cortex is a proliferative region provided with stem cells, and newly formed cells from that region differentiate and migrate centripetally through the $\mathrm{ZF}$ into the zona reticularis (ZR), where they undergo apoptosis $(31,51-53,56,68-74)$.

As shown by the number of nuclei profile of adrenocortical cells per unit area, enhanced proliferative activity of the ZG cells of ACTH- and NMU-treated rats was not accompanied by cellular hyperplasia. Thus, our present findings demonstrate that exogenous NMU may stimulate primarily proliferation of the cortical ZG cells in ACTH-administered rats, although at high doses of exogenous corticotropin an opposite effect occurred.

In conclusion, our recent studies reveal that NMU exerts a potent and complex modulatory effect on the proliferative activity of rat adrenal cortex. In primary adrenocortical cell cultures NMU directly stimulates proliferation of cells, while in vivo immature rat adrenocortical cells do not respond to NMU administration (28). NMU also exerts a potent proliferogenic effect on enucleation-induced adrenal growth (27) and, as documented by present results, on ACTH-induced adrenocortical growth. On the contrary, NMU exerts a potent inhibitory effect on unilateral adrenalectomy-induced compensatory adrenal growth (29). Accumulatively, our data suggest that NMU effects on proliferation of adrenocortical 
cells in vivo are mediated neither by adrenal medulla nor by alteration in blood ACTH concentrations, which are not modified in compensatory adrenal growth and adrenocortical regeneration. Conversely, it could be hypothesized that in vivo NMU effects on proliferative activity of rat adrenocortical cells may be mediated primarily via the nervous system.

\section{Acknowledgements}

This study was conducted in partial fullfilment of the $\mathrm{PhD}$ thesis requirement for Dr Marcin Trejter of the Poznan University of Medical Sciences, Poland.

\section{References}

1. Brighton PJ, Szekeres PG and Willars GB: Neuromedin U and its receptors: structure, function, and physiological roles. Pharmacol Rev 56: 231-248, 2004.

2. Malendowicz LK: Involvement of neuropeptides in the regulation of growth, structure and function of the adrenal cortex. Histol Histopath 8: 173-186, 1993.

3. Malendowicz LK: Role of neuromedins in the regulation of adrenocortical function. Horm Metab Res 30: 374-384, 1998.

4. Malendowicz LK, Nussdorfer GG, Nowak KW and Mazzocchi G: Effects of neuromedin U-8 on the rat pituitary-adrenocortical axis. In Vivo 7: 419-422, 1993.

5. Malendowicz LK and Nussdorfer GG: Neuromedin U (NMU)-23, but not NMU-8, inhibits basal corticosterone secretion by isolated zona fasciculata-reticularis cells of the rat adrenal cortex. Biomed Res 48: 291-294, 1993.

6. Malendowicz LK, Andreis PG, Markowska A, Nowak M, Warchol JB, Neri G and Nussdorfer GG: Effects of neuromedin U-8 on the secretory activity of the rat adrenal-cortex: evidence for an indirect action requiring the presence of the zona medullaris. Res Exp Med 194: 69-79, 1994.

7. Malendowicz LK, Nussdorfer GG, Markowska A, Tortorella C, Nowak $\mathrm{M}$ and Warchol JB: Effects of neuromedin-U (NmU)-8 on the rat hypothalamo-pituitary-adrenal axis: evidence of a direct effect of NmU-8 on the adrenal-gland. Neuropeptides 26: 47-53, 1994.

8. Malendowicz LK and Markowska A: Neuromedins and their involvement in the regulation of growth, structure and function of the adrenal cortex. Histol Histopathol 9: 591-601, 1994.

9. Niimi M, Murao K and Taminato T: Central administration of neuromedin $\mathrm{U}$ activates neurons in ventrobasal hypothalamus and brainstem. Endocrine 16: 201-206, 2001.

10. Ivanov TR, Lawrence CB, Stanley PJ and Luckman SM: Evaluation of neuromedin $U$ actions in energy homeostasis and pituitary function. Endocrinology 143: 3813-3821, 2002.

11. Ozaki Y, Onaka T, Nakazato M, Saito J, Kanemoto K, Matsumoto T and Ueta Y: Centrally administered neuromedin $\mathrm{U}$ activates neurosecretion and induction of C-Fos messenger ribonucleic acid in the paraventricular and supraoptic nuclei of rat. Endocrinology 143: 4320-4329, 2002.

12. Wren AM, Small CJ, Abbott CR, Jethwa PH, Kennedy AR, Murphy KG, Stanley SA, Zollner AN, Ghatei MA and Bloom SR: Hypothalamic actions of neuromedin U. Endocrinology 143: 4227-4234, 2002.

13. Yokota M, Ozaki Y, Sakamoto F, Yamada S, Saito J, Fujihara H and Ueta Y: Fos expression in CRF-containing neurons in the rat paraventricular nucleus after central administration of neuromedin U. Stress 7: 109-112, 2004.

14. Thompson EL, Murphy KG, Todd JF, Martin NM, Small CJ, Ghatei MA, and Bloom SR: Chronic administration of NMU into the paraventricular nucleus stimulates the HPA axis but does not influence food intake or body weight. Biochem Biophys Res Commun 323: 65-71, 2004.

15. Ueta Y, Ozaki Y and Saito J: Novel G-protein coupled receptor ligands and neurohypophysial hormones. J Neuroendocrinol 16 : 378-382, 2004

16. Dallman MF: Control of adrenocortical growth in vivo. Endocr Res 10: 213-242, 1984-1985.

17. Taki TM and Nickerson PA: Differentiation and proliferation of adrenocortical cells during the early stages of regeneration. Lab Invest 53: 91-100, 1985.
18. Ulrich-Lay YM and Engeland WC: Hyperinnervation during adrenal regeneration influences the rate of functional recovery. Neuroendocrinology 71: 107-123, 2000.

19. Markowska A, Neri G, Hochol A, Nowak M, Nussdorfer GG and Malendowicz LK: Effects of leptin and leptin fragments on steroid secretion and proliferative activity of regenerating rat adrenal cortex. Int J Mol Med 13: 139-141, 2004.

20. Malendowicz LK, Rebuffat P, Tortorella C, Nussdorfer GG, Ziolkowska A and Hochol A: Effects of met-enkephalin on cell proliferation in different models of adrenocortical-cell growth. Int J Mol Med 15: 841-845, 2005.

21. Trejter M, Carraro G, Rucinski M, Hochol A, Rebuffat P, Nussdorfer GG and Malendowicz LK: Arginin-vasopressin regulates proliferative activity of the regenerating rat adrenal cortex. Int J Mol Med 15: 993-997, 2005.

22. Engeland WC and Dallman MF: Neural mediation of compensatory adrenal growth. Endocrinology 99: 1659-1662, 1976.

23. Dallman MF, Engeland WC and Shinsako J: Compensatory adrenal growth: a neurally mediated reflex. Am J Physiol 231: 408-414, 1976

24. Dallman MF, Engeland WC and McBride MH: The neural regulation of compensatory adrenal growth. Ann NY Acad Sci 297: 373-392, 1977.

25. Dallman MF, Engeland WC, Holzwarth MA and Scholz PM: Adrenocorticotropin inhibits compensatory adrenal growth after unilateral adrenalectomy. Endocrinology 107: 1397-1404, 1980.

26. Townsend SF, Dallman MF and Miller WL: Rat insulin-like growth factor-I and -II mRNAs are unchanged during compensatory adrenal growth but decrease during ACTHinduced adrenal growth. J Biol Chem 265: 22117-22122, 1990.

27. Trejter M, Neri G, Rucinski M, Majchrzak M, Nussdorfer GG and Malendowicz LK: Neuromedin U stimulates enucleationinduced adrenocortical proliferation in the rat. Int J Mol Med 21: 683-687, 2008

28. Ziolkowska A, Macchi C, Trejter MN, Rucinski M, Nowak M, Nussdorfer GG and Malendowicz LK: Neuromedin U effects on rat adrenocortical cells: in vitro and in vivo studies. Int J Mol Med 21: 303-307, 2008 .

29. Malendowicz LK, Guidolin D, Trejter M, Porzionato A, Rucinski M, De Caro R and Nowak M: Neuromedin U inhibits unilateral-adrenalectomy induced compensatory adrenal growth in the rat. Peptides (In press).

30. Michat L and Nouet IC: Variations nycthemerales de l'activite mitotique dans la corticosurrenale du rat male. CR Soc Biol 169: 1421-1424, 1975

31. Stachowiak A, Nussdorfer GG and Malendowicz LK: Proliferation and distribution of adrenocortical cells in the gland of ACTH- or dexamethasone-treated rats. Histol Histopathol 5: 25-29, 1990.

32. Malendowicz LK, Neri G, Jedrzejczak N, Hochol A and Nussdorfer GG: Effects of recombinant murine leptin [1-147] and leptin fragment 116-130 on steroid secretion and proliferative activity of the regenerating rat adrenal cortex. Endocr Res 26: 109-118, 2000.

33. Hochol A, Albertin G, Nussdorfer GG, Spinazzi R, Ziolkowska A, Rucinski M and Malendowicz LK: Effects of neuropeptides B and $\mathrm{W}$ on the secretion and growth of rat adrenocortical cells. Int J Mol Med 14: 843-847, 2004.

34. Rucinski M, Spinazzi R, Ziolkowska A, Nussdorfer GG and Malendowicz LK: Effects of beacon on the rat pituitaryadrenocortical axis response to stress. Int J Mol Med 16: 297-299, 2005.

35. Hosoya M, Moriya T, Kawamata Y, Ohkubo S, Fujii R, Matsui H, Shintani Y, Fukusumi S, Habata Y, Hinuma S, Onda H, Nishimura $\mathrm{O}$ and Fujino $\mathrm{M}$ : Identification and functional characterization of a novel subtype of neuromedin $U$ receptor. J Biol Chem 275: 29528-29532, 2000.

36. Raddatz R, Wilson AE, Artymyshyn R, Bonini JA, Borowsky B, Boteju LW, Zhou S, Kouranova EV, Nagorny R, Guevarra MS, Dai M, Lerman GS, Vaysse PJ, Branchek TA, Gerald C, Forray $\mathrm{C}$ and Adham N: Identification and characterization of two neuromedin $U$ receptors differentially expressed in peripheral tissues and the central nervous system. J Biol Chem 275: 32452-32459, 2000.

37. Shan LX, Qiao XD, Crona JH, Behan J, Wang S, Laz T, Bayne M, Gustafson EL, Monsma FJ and Hedrick JA: Identification of a novel neuromedin $U$ receptor subtype expressed in the central nervous system. J Biol Chem 275: 39482-39486, 2000. 
38. Howard AD, Wang R, Pong SS, Mellin TN, Strack A, Guan XM, Zeng Z, Williams DL Jr, Feighner SD, Nunes CN, Murphy B, Stair JN, Yu H, Jiang Q, Clements MK, Tan CP, McKee KK, Hreniuk DL, McDonald TP, Lynch KR, Evans JF, Austin CP, Caskey CT, Van der Ploeg LH and Liu Q: Identification of receptors for neuromedin $\mathrm{U}$ and its role in feeding. Nature 406: $70-74,2000$

39. Hedrick JA, Morse K, Shan L, Qiao X, Pang L, Wang S, Laz T, Gustafson EL, Bayne M and Monsma JF: Identification of a human gastrointestinal tract and immune system receptor for the peptide neuromedin U. Mol Pharmacol 58: 870-875, 2000.

40. Westfall TD, McCafferty GP, Pullen M, Gruver S, Sulpizio AC, Aiyar VN, Disa J, Contino LC, Mannan IJ and Hieble JP: Characterisation of neuromedin $U$ effects in canine smoothmuscle. J Pharmacol Exp Ther 301: 987-992, 2001.

41. Szekeres PG, Muir AI, Spinage LD, Miller JE, Butler SI, Smith A, Rennie GI, Murdock PR, Fitzgerald LR, Wu H, McMillan LJ, Guerrera S, Vawter L, Elshourbagy NA, Mooney JL, Bergsma DJ, Wilson S and Chambers JK: Neuromedin U is a potent agonist at the orphan $\mathrm{G}$ protein-coupled receptor FM3. J Biol Chem 275: 20247-20250, 2000.

42. Fujii R, Hosoya M, Fukusami S, Kazamata Y, Habata Y, Hinuma S, Onda $\mathrm{H}$, Nishimura $\mathrm{O}$ and Fujino M: Identification of neuromedin $\mathrm{U}$ as the cognate ligand of the orphan $\mathrm{G}$ proteincoupled receptor FM-3. J Biol Chem 275: 21068-21074, 2000.

43. Graham ES, Turnbull Y, Fotheringham P, Nilaweera K, Mercer JG, Morgan PJ and Barrett P: Neuromedin U and neuromedin $\mathrm{U}$ receptor-2 expression in the mouse and rat hypothalamus: effects of nutritional status. J Neurochem 87 : 1165-1173, 2003.

44. Qiu DL, Chu CP, Shirasaka T, Nabekura T, Kunitake T, Kato K, Nakazato M, Katoh T and Kannan H: Neuromedin U depolarizes rat hypothalamic paraventricular nucleus neurons in vitro by enhancing IH channel activity. J Neurophysiol 90: 843-850, 2003.

45. Qiu DL, Chu CP, Tsukino H, Shirasaka T, Nakao H, Kato K, Kunitake T, Katoh T and Kannan H: Neuromedin U receptor-2 mRNA and HCN channels mRNA expression in NMU-sensitive neurons in rat hypothalamic paraventricular nucleus. Neurosci Lett 374: 69-72, 2005.

46. Ida T, Mori K, Miyazato M, Egi Y, Abe S, Nakahara K, Nishihara M, Kangawa K and Murakami N: Neuromedin S is a novel anorexigenic hormone. Endocrinology 146: 4217-4223, 2005.

47. Mori K, Miyazato M, Ida T, Murakami N, Serino R, Ueta Y, Kojima $M$ and Kangawa K: Identification of neuromedin $S$ and its possible role in the mammalian circadian oscillator system. EMBO J 26: 325-335, 2005.

48. Rucinski M, Ziolkowska A, Neri G, Trejter M, Zemleduch T, Tyczewska M, Nussdorfer GG and Malendowicz LK: Neuromedin S, neuromedin $\mathrm{U}$ and their receptors in the hypothalamus and endocrine glands of the rat. Int J Mol Med 20: 255-259, 2007

49. Farese RV and Reddy WJ: Observations on the interrelations between adrenal protein, RNA and DNA during prolonged ACTH administration. Biochem Biophys Acta 76: 145-148, 1963.

50. Imrie RC, Ramaiah TR, Antoni F and Hutchison WC: The effect of adrenocorticotropin on the nucleic acid metabolism of the rat adrenal gland. J Endocrinol 32: 303-312, 1965.

51. Belloni AS, Mazzocchi G, Meneghelli V and Nussdorfer GG: Cytogenesis in the rat adrenal cortex: evidence for an $\mathrm{ACTH}-$ induced centripetal cell migration from the zona glomerulosa. Arch Anat Histol Embryol 61: 195-205, 1978.

52. Payet N, Lehoux JG and Isler H: Effect of ACTH on the proliferative and secretory activities of the adrenal glomerulosa. Acta Endocrinol 93: 365-374, 1980.

53. Malendowicz LK: A correlated stereological and functional studies on the long-term effects of ACTH on rat adrenal cortex. Folia Histochem Cytobiol 24: 203-211, 1986.

54. Mazzocchi G, Malendowicz LK, Rebuffat P, Robba C, Gottardo G and Nussdorfer GG: Short- and long-term effects of ACTH on the adrenal zona glomerulosa of the rat. A coupled stereological and enzymological study. Cell Tissue Res 243: $303-310,1986$
55. Miskowiak B, Kasprzak A and Malendowicz LK: Comparative stereological studies on the effects of long term CRF and ACTH treatment on the cortex of the suprarenal gland. J Anat 146: 167-172, 1986

56. Nussdorfer GG: Cytophysiology of the adrenal cortex. Int Rev Cytol 98: 1-405,1986.

57. Malendowicz LK, Nussdorfer GG, Markowska A and Nowak KW: Analysis of the preventive action of ACTH on dexamethasoneinduced adrenocortical atrophy in the rat. Cytobios 71: 191-199, 1992.

58. Ramachandran J and Suyama AT: Inhibition of replication of normal adrenocortical cells in culture by adrenocorticotropin Proc Natl Acad Sci USA 72: 113-117, 1975

59. Rybak SM and Ramachandran J: Primary culture of normal rat adrenocortical cells. I. Culture conditions for optimal growth and function. In Vitro 17: 599-604, 1981

60. Ziolkowska A, Belloni AS, Nussdorfer GG, Nowak M and Malendowicz LK: Endocrine disruptors and rat adrenocortical function: studies on freshly dispersed and cultured cells. Int J Mol Med 18: 1165-1168, 2006.

61. Hinson JP, Vinson GP, Whitehouse BJ and Price GM: Effects of stimulation on steroid output and perfusion medium flow rate in the isolated perfused rat adrenal gland in situ. J Endocrinol 109: 279-285, 1986.

62. Hinson JP, Vinson GP, Kapas S and Teja R: The relationship between adrenal vascular events and steroid secretion: the role of mast cells and endothelin. J Steroid Biochem Mol Biol 40: 381-389, 1991

63. Thomas M, Keramidas M, Monchaux E and Feige JJ: Role of adrenocorticotropic hormone in the development and maintenance of the adrenal cortical vasculature. Microsc Res Tech 61: 247-251, 2003.

64. Thomas M, Keramidas M, Monchaux E and Feige JJ: Dual hormonal regulation of endocrine tissue mass and vasculature by adrenocorticotropin in the adrenal cortex. Endocrinology 145: 4320-4329, 2004

65. Minamino N, Kangawa K and Matsuo H: Neuromedin U-8 and U-25: novel uterus stimulating and hypertensive peptides identified in porcine spinal cord. Biochem Biophys Res Commun 130: 1078-1085, 1985

66. Chu C, Jin Q, Kunitake T, Kato K, Nabekura T, Nakazato M, Kangawa $\mathrm{K}$ and Kannan $\mathrm{H}$ : Cardiovascular actions of central neuromedin U in conscious rats. Regul Pept 105: 29-34, 2002.

67. Jones NA, Morton MF, Prendergast CE, Powell GL, Shankley NP and Hollingsworth SJ: Neuromedin U stimulates contraction of human long saphenous vein and gastrointestinal smooth muscle in vitro. Regul Pept 136: 109-116, 2006.

68. Bertholet JY: Proliferative activity and cell migration in the adrenal cortex of fetal and neonatal rats: an autoradiographic study. J Endocrinol 87: 1-9, 1980.

69. Malendowicz LK and Jachimowicz B: Sex differences in adrenocortical structure and function. XI. Autoradiographic studies on cell proliferation and turnover in the adrenal cortex of the male and female rat and its dependence on testosterone and estradiol. Cell Tissue Res 227: 651-657, 1982.

70. Zajicek G, Ariel I and Arber N: The streaming adrenal cortex: direct evidence of centripetal migration of adrenocytes by estimation of cell turnover rate. J Endocrinol 111: 477-482, 1986.

71. McNicol AM and Duffy AE: A study of cell migration in the adrenal cortex of the rat using bromodeoxyuridine. Cell Tissue Kinet 20: 519-526, 1987 .

72. Morley SD, Viard I, Chung BC, Ikeda Y, Parker KL and Mullins JJ: Variegated expression of a mouse steroid 21hydroxylase/beta-galactosidase transgene suggests centripetal migration of adrenocortical cells. Mol Endocrinol 10: 585-598, 1996.

73. Mitani F, Mukai K, Miyamoto H, Suematsu M and Ishimura Y: Development of functional zonation in the rat adrenal cortex. Endocrinology 140: 3342-3353, 1999.

74. Rebuffat P, Macchi C, Malendowicz LK and Nussdorfer GG: Up-regulation of adrenomedullin receptor gene expression in activated local stem cells during rat adrenal regeneration. Int $\mathbf{J}$ Mol Med 20: 855-858, 2007. 